\title{
Pengaruh Likuiditas, Leverage, Profitabilitas dan Ukuran Perusahaan terhadap Financial Distress pada Perusahaan Barang Konsumsi yang Terdaftar di BEI Tahun 2016-2020.
}

\author{
Friska Darnawaty Sitorus ${ }^{1}$, Ferdinand Hernandy ${ }^{2}$, Wensly Triskietanto ${ }^{3}$, Audi Angela ${ }^{4}$, \\ Vanessa ${ }^{5}$ \\ Universitas Prima Indonesia ${ }^{1}$, Universitas Prima Indonesia ${ }^{2}$, Universitas Prima Indonesia ${ }^{3}$, \\ Universitas Prima Indonesia ${ }^{4}$, Universitas Prima Indonesia ${ }^{5}$ \\ friska.darnawaty@yahoo.com ${ }^{1}$, hernandyf@gmail.com ${ }^{2}$, triskietanto123@gmail.com $^{3}$, \\ audiangela07@gmail.com ${ }^{4}$, vanessasim18@gmail.com
}

*Corresponding Author

Diajukan : 4 Oktober 2021

Disetujui : : 19 Oktober 2021

Dipublikasi : : 1 Januari 2022

\begin{abstract}
The purpose of the researcher's research is to study and analyze the effect of liquidity using proxies CR (Current Ratio), leverage using proxies DAR (Debt to Asset Ratio), profitability using proxies RoA (Return on Assets), and Firm size against Financial Distress that occurred in consumer goods companies listed on the IDX in the period 2016 - 2020. This research using Quantity Method. Quantity Method is a technique that utilizes mathematical models in the form of numbers. The population in the consumer goods company is 90 companies and is selected using purposive sampling. Then the number of samples used amounted to 34 companies. The results in the partial tests, the liquidity variable using proxy Cash Ratio has a positive impact and not significant to Financial Distress. Leverage using DAR and company size with the calculation of Ln Total Assets are partially insignificant and have no negative impact on Financial Distress. Meanwhile, profitability by using RoA is partially significant and has a positive impact on Financial Distress and simultaneous test results : Liquidity (CR), Leverage (DAR), Profitability (RoA), and Firm Size have a significant effect on Financial Distress in consumer goods companies listed on the IDX in the period 2016 - 2020.
\end{abstract}

\section{Key Word : Financial Distress ,Firm Size, Leverage ,Liquidity, Profitability}

\section{I.1 Latar Belakang}

\section{PENDAHULUAN}

Banyaknya perusahaan yang berkembang dari waktu ke waktu mengakibatkan perusahaan mampu bersaing ketat dan berinovasi dalam produknya sehingga perusahaannya dapat bertahan dari perusahaan lain dan memperoleh keuntungan. Banyak sekali perusahaan perusahaan lama mencari ide agar dapat menyaingi perusahaan-perusahaan lain seperti membuat produk baru, berinovasi dalam produknya atau mengekspansi bisnisnya. Untuk mengekspansi bisnis, manajemen perusahaan sangat penting dalam melakukan proses ekspansi agar dapat berjalan dengan lancar. Apabila manajemen perusahaan tidak pandai dalam mengelola keuangan dan proses ekspansi bisnisnya tidak berjalan dengan lancar, maka perusahaan tentunya dihadapkan pada kebangkrutan atau istilah akuntansi "financial distress". Dikarenakan untuk mengekspansi bisnis tidak bisa mengandalkan harta, melainkan harus melakukan pinjaman. Pengertian Financial Distress / penurunan kondisi keuangan adalah suatu keadaan dimana perusahaan tidak dapat melanjutkan aktivitas bisnisnya dikarenakan tidak dapat membayar 
kewajiban pada waktu yang sudah ditentukan. selain itu financial distress bisa diartikan sebagai keadaan dimana suatu usaha mengalami krisis keuangan. Financial Distress biasanya diakibatkan oleh entitas yang gagal membayar hutang debitur dikarenakan entitas kehabisan dananya untuk meneruskan operasional entitas.

Perusahaan kecil cenderung dihadapi Financial distress, sebab perusahaan kecil sulit untuk mendapatkan pinjaman dari investor ataupun bank sedangkan perusahaan besar sering mendapatkan kesempatan diberikan pinjaman dari investor atau bank dikarenakan perusahaan besar memberikan profit yang tinggi apabila jika dibandingkan dengan perusahaan kecil yang sulit dalam memperoleh profit besar. Rentan sekali perusahaan besar yang memperoleh profit besar akan mengalami financial distress (Setiawan et al., 2017). Meskipun begitu tidak menutup kemungkinan bagi perusahaan besar untuk mengalami kondisi financial distress meskipun mampu mendapatkan pinjaman. Apabila kinerja perusahaan memburuk, maka kemungkinan besar perusahaan akan mengalami kebangkrutan / pailit.

Seperti kasus yang menimpa PT Sari Wangi, siapa yang tidak kenal PT Sari Wangi, perusahaan yang memproduksi teh celup yang bernama Teh SariWangi. Pada tahun 2015, perusahaan ini mengalami kejadian yang diluar dugaan, dimana perusahaan ini melakukan pengembangan teknologi penyiraman air yang telah mengeluarkan biaya sangat besar. Untuk melakukan kegiatan tersebut, PT Sari Wangi dan anak perusahaannya melakukan pinjaman dana kepada beberapa kreditur yang mencapai 1.5 trilliun akan tetapi output dari kegiatan tersebut tidak sesuai dengan ekspektasinya. Sehingga PT SariWangi terhambat dalam melakukan pembayaran dikarenakan utang yang cukup besar dan pendapatan yang tidak sesuai dengan prediksi. Terdapat lima bank yang menyajikan tagihan pada waktu itu. Pada tahun 2018, PT Sariwangi dinyatakan bangkrut oleh Niaga Jakarta Pusat dikarenakan tidak kompeten dalam pengembalian utang sebesar Rp 1 trilliun (Jatmiko, 2018). Berikut data fenomena yang periset kumpulkan dari berbagai perusahaan untuk dijadikan sebagai contoh kasus selain dari kasus PT SariWangi.

Tabel Fenomena Penelitian

\begin{tabular}{|c|c|c|c|c|c|c|}
\hline KODE & Tahun & $\begin{array}{c}\text { Asset } \\
\text { Lancar }\end{array}$ & Total Asset & $\begin{array}{c}\text { Kewajiban } \\
\text { Jangka Pendek }\end{array}$ & $\begin{array}{c}\text { Total } \\
\text { Kewajiban }\end{array}$ & Laba Bersih \\
\hline \multirow{4}{*}{ ADES } & 2016 & Rp 319.614 & Rp 1.087.093 & Rp 195.466 & $\operatorname{Rp} 383.091$ & $\begin{array}{ll}\mathrm{Rp} & 55.951\end{array}$ \\
\hline & 2017 & Rp 294.244 & Rp 1.134.480 & Rp 244.888 & $\operatorname{Rp} 417.225$ & Rp 38.242 \\
\hline & 2018 & Rp 364.138 & Rp 1.245.413 & Rp 262.397 & Rp 399.361 & $\begin{array}{ll}\mathrm{Rp} & 52.958\end{array}$ \\
\hline & 2019 & $\operatorname{Rp} 351.120$ & $\mathrm{Rp} \quad 822.375$ & Rp 175.191 & Rp 254.438 & $\begin{array}{ll}\mathrm{Rp} & 83.885\end{array}$ \\
\hline \multirow{4}{*}{ SKLT } & 2016 & Rp 222.687 & Rp $\quad 345.553$ & Rp 568.240 & Rp 169.303 & Rp 102.786 \\
\hline & 2017 & Rp 267.129 & $\mathrm{Rp} \quad 369.155$ & $\operatorname{Rp} 636.284$ & Rp 211.493 & Rp 117.221 \\
\hline & 2018 & Rp 356.736 & Rp $\quad 390.558$ & Rp 747.294 & Rp 291.349 & Rp 116.709 \\
\hline & 2019 & Rp 378.352 & $\begin{array}{ll}\mathrm{Rp} & 412.493 \\
\end{array}$ & Rp 790.845 & Rp 293.281 & Rp 117.182 \\
\hline \multirow{4}{*}{ SKBM } & 2016 & Rp 519.270 & $\operatorname{Rp} 1.001 .657$ & $\operatorname{Rp} 468.980$ & $\operatorname{Rp} 633.268$ & $\begin{array}{ll}\mathrm{Rp} & 22.545\end{array}$ \\
\hline & 2017 & $\operatorname{Rp} 836.640$ & $\operatorname{Rp} 1.623 .028$ & Rp 511.597 & Rp 599.790 & $\begin{array}{ll}\mathrm{Rp} & 25.880\end{array}$ \\
\hline & 2018 & $\mathrm{Rp} 851.410$ & $\mathrm{Rp} 1.771 .366$ & Rp 615.507 & $\operatorname{Rp} 730.790$ & $\begin{array}{ll}\mathrm{Rp} & 15.955\end{array}$ \\
\hline & 2019 & Rp 889.744 & $\mathrm{Rp} 1.820 .384$ & Rp 668.932 & Rp 784.563 & 957 \\
\hline
\end{tabular}

Sumber : www.idx.co.id

Kejadian yang dialami pada PT ADES, dimana Asset Lancar pada tahun 2016-2017 mengalami penurunan sebesar 7,9\%. Sedangkan untuk kewajiban jangka pendeknya mengalami peningkatan sebesar 25\%. Perbandingan ini dibandingkan dengan 
menggunakan rasio likuiditas dengan proksi CR dimana apabila tingkat persentase CR rendah maka besar kemungkinannya bagi entitas menghadapi kondisi kesulitan keuangan. (Widati \& Pratama, 2015)

Pada PT SKLT, dimana Total Kewajiban tahun 2016 - 2017 meningkat sebesar 24\% sedangkan untuk Total Asset pada tahun 2016-2017 bertambah 6,8\% dan pada tahun 2017-2018 Total Kewajiban mengalami kenaikan 37\% dan Total Asset nya mengalami kenaikan sebesar $5,7 \%$. Jika dibandingkan setiap tahunnya antara total kewajiban dan total asset, kenaikan total kewajiban lebih besar daripada total asset. Menurut (Yudhistira, 2019) DAR yang tinggi menunjukkan status suatu perusahaan kurang baik dikarenakan beban perusahaan meningkat dan akhirnya mengarah pada kondisi kesulitan keuangan.

Pada PT. SKBM, dimana menggunakan rasio profitabilitas yaitu RoA menyajikan data bahwa laba bersih dari tahun 2017 - 2018 menurun 38\% dan di tahun 2018 - 2019 menurun 94\%. Sehingga laba di tahun 2018-2019 mengalami penurunan sangat drastis apabila dibandingkan dengan laba di tahun sebelumnya. Menurut Firdiana (2016) menyatakan bahwa perusahaan yang memanifestasikan perbandingan ROA yang tinggi akan menciptakan peluang yang kecil dalam menghadapi financial distress. Sedangkan rendahnya ROA menyiratkan kemampuan finansial yang buruk yang akan memicu merosotnya daya laba beserta dengan probabilitas financial distress yang tinggi.

Berdasarkan informasi dan kasus sebelumnya, periset mengharapkan agar entitas lain tidak mengalami kasus yang serupa dan periset ingin menganalisa apakah rasio keuangan yang digunakan dapat mempengaruhi financial distress atau tidak. Sehingga periset memilih judul : "Pengaruh Likuiditas, Leverage, Profitabilitas, dan Ukuran Perusahaan terhadap Financial Distress Pada Perusahaan Barang Konsumsi yang Terdaftar Di BEI Periode 2016 - 2020."

\section{Rumusan Masalah}

Adapun rumusan masalah dalam riset ini adalah :

1. Bagaimana Pengaruh Likuiditas, Leverage, Profitabilitas dan Ukuran Perusahaan terhadap Financial Distress pada perusahaan barang konsumsi yang terdaftar di BEI periode 2016 $-2020$.

2. Bagaimana Pengaruh Likuiditas (Current Ratio) terhadap Financial Distress pada perusahaan barang konsumsi yang terdaftar di BEI periode 2016 - 2020.

3. Bagaimana Pengaruh Leverage (Debt to Asset Ratio) terhadap Financial Distress pada perusahaan barang konsumsi yang terdaftar di BEI periode 2016 - 2020.

4. Bagaimana Pengaruh Profitabilitas (Return on Asset) terhadap Financial Distress pada perusahaan barang konsumsi yang terdaftar di BEI periode 2016 - 2020.

5. Bagaimana Pengaruh Ukuran Perusahaan terhadap Financial Distress pada perusahaan barang konsumsi yang terdaftar di BEI periode 2016 - 2020.

\section{Likuiditas (Current Ratio)}

\section{LITERATUR REVIEW}

Menurut Kasmir (2016),CR yang merupakan bagian dari likuiditas yang tujuan pemakaiannya untuk menilai kemampuan entitas saat membayar kewajiban yang akan kadaluwarsa saat penagihan secara keseluruhan.

$$
\text { Current Ratio }=\frac{\text { Asset Lancar }}{\text { Hutang Lancar }}
$$

Sumber : Kasmir (2016)

\section{Leverage (Debt to Assets Ratio)}

Menurut Kasmir (2016:156),DAR merupakan bagian dari leverage yang memperkirakan komparasi total kewajiban terhadap total aset. Dengan pengertian, seberapa banyak total kewajiban yang terdapat di suatu entitas sehingga mempengaruhi pengelolaan aktiva.

Debt to Assets Ratio $(D A R)=\frac{\text { Total Hutang }}{\text { Total Asset }}$ 


\section{Sumber : Kasmir (2016)}

\section{Profitabilitas (Return on Assets)}

Menurut Kasmir (2016:201),RoA diaplikasikan untuk membuktikan keahlian entitas untuk menghasilkan keuntungan dengan memakai total asset milik entitasnya.

Return on Assets $(R o A)=\frac{\text { Net Income }}{\text { Total Asset }}$

Sumber :Brigham dan Houston dalam Satriana (2017:15)

\section{Ukuran Perusahaan}

Menurut Riyanto (2013), Ukuran perusahaan ialah suatu pengklasifikasian skala usaha yang ditinjau baik melalui aktiva, pemasaran dan modal.

Ukuran Perusahaan $=$ Ln Total Asset

Sumber : Liang (2019)

\section{Financial Distress}

Menurut hanafi (2014:637), Financial distress mampu diilustrasikan sebagai dua titik radikal yakni daripada short term liability menuju insoluble (rasio hutang yang jumlahnya lebih banyak melebihi aktiva) memperlihatkan bahwa short term liability financial distress umumnya bersifat temporer, namun mampu bertumbuh ke arah negatif.

$Z "=0,717 X_{1}+0,847 X_{2}+3,107 X_{3}+0,420 X_{4}+0,998 X_{5}$

Keterangan:

$\mathrm{X}_{1}=$ (Aktiva lancar-Utang Lancar) / Total Aktiva

$\mathrm{X}_{2}=$ Laba yang ditahan / Total Aktiva

$\mathrm{X}_{3}=$ Laba sebelum bunga dan pajak / Total Aktiva

$\mathrm{X}_{4}=$ Nilai pasar modal / Nilai buku hutang

$\mathrm{X}_{5}=$ Penjualan $/$ Total aktiva

Sumber : Noviandani, dkk 2018

\section{Pengaruh Likuiditas (CR) terhadap Financial Distress}

Carolina, I. Marpaung dkk (2017) mengungkapkan Perusahaan dengan likuiditas tinggi mengisyaratkan bahwa entitas dengan sejumlah current assets bersedia melunasi current liabilities akhirnya entitas terlepas dari situasi kondisi kesulitan keuangan.

Stephanie, Lindawati $\operatorname{dkk}(2020)$ menyatakan bahwa Likuiditas tinggi membuktikan entitas mempunyai current assets yang mencakupi current liabilities, hingga tingkat ketidakmampuan perusahaan dalam membayar lebih kecil. Dalam penelitiannya menunjukkan bahwa variabel likuiditas mempengaruhi kondisi kesulitan keuangan.

H1: Likuiditas(CR) secara parsial mempengaruhi Financial Distress.

\section{Pengaruh Leverage (DAR) Terhadap Financial Distress}

Leverage berasal dari suatu aktivitas atau kemampuan dalam menggunakan dana serta aset perusahaan yang memiliki biaya tetap dari pihak lain yang bentuk Hutang yang dibelanjakan. Pengaruh leverage yang sangat tinggi mengakibatkan entitas memiliki sejumlah kewajiban yang tinggi sehingga entitas sulit melakukan pembayarannya saat jatuh tempo serta menyebabkan kondisi kesulitan keuangan. (Rohmadini, Saifi dkk, 2018).

Silalahi, dkk. (2018) mengungkapkan pengukuran leverage yang memanfaatkan variabel DAR berdampak negatif substansial terhadap Financial Distress (kondisi kesulitan keuangan).

$\mathrm{H}_{2} \quad$ : Leverage(DAR) secara parsial mempengaruhi Financial Distress.

\section{Pengaruh Profitabilitas (RoA) Terhadap Financial Distress}

Menurut (Aryadi, 2018) Nilai profitabilitas yang tinggi dapat memberikan sinyal positif pada bagian eksternal dimana kinerja perusahaan mengalami peningkatan. Semakin besar perusahaan dengan memperoleh keuntungan, perusahaan akan terhindar dari kondisi kesulitan 
keuangan. Begitu pula sebaliknya, dimana semakin kecil perusahaan untuk memperoleh keuntungan, kinerja perusahaan telah menurun atau terjadinya masalah keuangan.

Dalam penelitian (Oktavianti, Hizai, dkk, 2020) menyatakan bahwa variabel profitabilitas secara parsial mempengaruhi kesulitan keuangan.

$\mathrm{H}_{3} \quad$ : Profitabilitas(RoA) secara parsial mempengaruhi Financial Distress.

\section{Pengaruh Ukuran Perusahaan Terhadap Financial Distress}

Menurut (Eminingtyas, 2017), Firm Size (Ukuran perusahaan) menyajikan informasi yang ada di perusahaan baik secara intern maupun extern, Pengukuran perusahaan pada kondisi kesulitan keuangan pengaruhnya ini disebabkan total asset yang dimiliki perusahaan sehingga dapat membayar utang yang tersedia pada waktu yang akan datang.

Azalia \& Rahayu (2019) menyimpulkan ukuran perusahaan mempunyai pengaruh signifikan negatif kepada kondisi kesulitan keuangan. Semakin naiknya total aset entitas maka semakin meningkatnya entitas dapat membayar kewajibannya di waktu mendatang.

$\mathrm{H}_{4} \quad$ : Ukuran Perusahaan secara parsial mempengaruhi Financial Distress.

\section{Metode Penelitian}

\section{METODE}

Riset yang dilakukan oleh periset adalah dengan memakai teknik penelitian kuantitatif. Sugiono (2017:14) mendefinisikan penelitian kuantitatif menjadi teknik penelitian yang didasari oleh ideologi yang konkret, sebagai acuan me-riset population atau sample tertentu, teknik dalam pengumpulan sampel yang diambil secara acak, pengumpulan data memakai instrumen riset, analisis data bersifat kuantitatif/statistik, dalam mengevaluasi hipotesa yang ditujukan.

\section{Populasi dan Sampel}

Population / populasi sebagai zona abstraksi yang berisi obyek dataatau subyek data yang terdiri dari kualitas \& karakteristik tertentu dimana ditentukan kepada para periset dengan tujuan mempelajari dan menarik kesimpulannya. (Sugiyono, 2018)

Sampel merupakan segmen dari populasi. Dalam penarikan sampel ini, perusahaan harus memiliki kelengkapan data tahun serta aspek - aspek yang dibutuhkan dalam riset.

Tabel 1 Kriteria Pengambilan Sampel

\begin{tabular}{|c|c|}
\hline Keterangan & Total \\
\hline $\begin{array}{l}\text { Entitas Bisnis/Perusahaan Barang Konsumsi } \\
\text { yang Tercantum dan Terdaftar di BEI }\end{array}$ & 90 \\
\hline $\begin{array}{l}\text { Entitas Bisnis/Perusahaan Barang Konsumsi } \\
\text { yang tidak berlaba selama masa } 2016-2020\end{array}$ & (32) \\
\hline $\begin{array}{l}\text { Entitas Bisnis/Perusahaan Barang Konsumsi } \\
\text { yang tidak memunculkan Laporan Keuangan } \\
\text { pada masa 2016-2020 }\end{array}$ & (24) \\
\hline $\begin{array}{l}\text { Jumlah Entitas Bisnis/Perusahaan yang dapat } \\
\text { dijadikan sebagai sampel riset }\end{array}$ & 34 \\
\hline Data Observasi (34 x 5) & 170 \\
\hline
\end{tabular}

\section{Metode Pengumpulan Data,Jenis dan Sumber Data}

Metode pengumpulan data diperoleh dari metode dokumentasi. Dalam metode ini, periset mengakumulasi data berupa jurnal, laporan keuangan, berita serta E-book. Tipe Data yang dimanfaatkan pada riset ini yaitu Quantitative Data/Data Kuantitatif. Dan sumber data yang diaplikasikan kedalam riset ini yaitu Secondary Data/Data Sekunder. Sumber Secondary Data (Data Sekunder) dapat ditemukan secara indirectly dari Laporan Keuangan yang dipublikasikan seperti : di situs BEI www.idx.co.id. 


\section{HASIL}

\section{Statistik Deskriptif}

Total seluruh data yang diteliti terdapat 170 data yang dapat diperoleh dari 34 perusahaan dengan 5 tahun periode penelitian. Berikut tabel ini dapat dilihat gambaran data Terendah, Tertinggi, Mean beserta Standard Deviation dari tiap variabel yang diuji.

Tabel 1 Tabel Statistik Deskriptif

\begin{tabular}{|l|l|r|r|r|r|}
\hline \multicolumn{5}{|c|}{ Statistik Deskriptif } \\
\hline & $\mathrm{N}$ & Minimum & Maksimum & \multicolumn{1}{c|}{ Mean } & $\begin{array}{c}\text { Std. } \\
\text { Devisiasi }\end{array}$ \\
\hline CR & 170 & .606 & 8.638 & 2.37564 & 1.675370 \\
DAR & 170 & .141 & .811 & .45712 & .195484 \\
RoA & 170 & .001 & .527 & .09643 & .095970 \\
Ukuran & 170 & 13.250 & 18.910 & 15.70548 & 1.369398 \\
Financial & & & & & \\
D & 170 & 1.088 & 29.755 & 4.86970 & 4.232450 \\
Valid N & & & & & \\
(listwise) & 170 & & & & \\
\hline
\end{tabular}

Berdasarkan tabel diatas, diketahui Current Ratio messmpunyai nilai terendah sebanyak 0.606 yang didapatkan oleh PT. Unilever Indonesia Tbk. di tahun 2019 dan nilai tertinggi sebanyak 8.638 didapatkan oleh PT. Delta Djakarta Tbk. di tahun 2017. Hasil perhitungan rata ratanya adalah 2.37564 .

Diketahui Debt to Asset Ratio mempunyai nilai terendah sebanyak 0.141 yang didapatkan PT. Ultra Jaya Milk Industry Tbk. Saat periode 2018 dan nilai tertinggi sebanyak 0.811 didapatkan oleh PT. Midi Utama Indonesia Tbk. Saat periode 2017. Hasil perhitungan rata ratanya adalah 0.45712 .

Return on Assets diketahui mempunyai nilai terendah sebanyak 0.001 yang didapatkan PT. Sawit Sumbermas Sarana Tbk. di tahun 2019 dan nilai tertinggi sebanyak 0.527 yang didapatkan PT. Multi Bintang Indonesia Tbk. Saat periode 2017. Hasil perhitungan rata - ratanya yaitu 0.09643 .

Pada Ukuran perusahaan, nilai terendah sebanyak 13.250 didapatkan PT. Sekar Laut Tbk. Saat periode 2016 dan nilai tertinggi sebanyak 18.910 didapatkan PT. Indofood Sukses Makmur Tbk. di Tahun 2020. Hasil perhitungan rata - rata yang diperoleh adalah 15.70548.

Financial distress memiliki nilai terendah sebanyak 1.088 didapatkan oleh PT. Dharma Satya Nusantara Tbk. Di tahun 2016 dan nilai tertinggi sebanyak 29.755 didapatkan oleh PT. H.M. Sampoerna Tbk. di tahun 2017. Nilai rata-rata nya diperoleh 4.86970 .

\section{Uji Asumsi Klasik}

\section{Uji Normalitas}

Pengujian normalitas yakni yang dimanfaatkan dengan maksud untuk menunjukkan variabel bebas dan terikat berdistribusi secara normal ataupun tidak. (Ghozali, 2018)

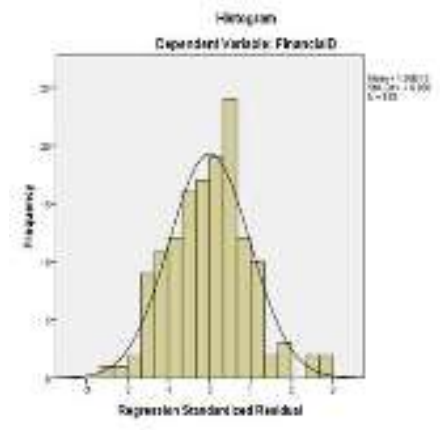

Gambar 1 Grafik Histogram setelah Outlier 


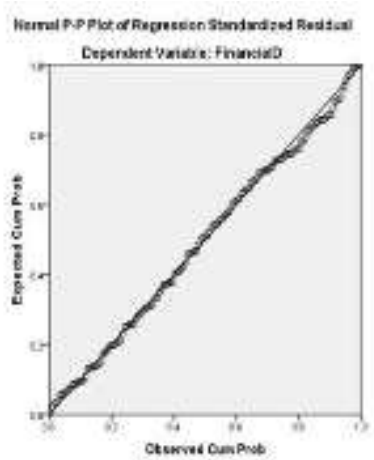

Gambar 2 Grafik P-Plot Uji Normalitas

Pada tampilan output gambar IV.1 diatas, dapat dilihat pada Grafik Histogram berbentuk lonceng di tengah maka data dapat dianggap terdistribusi secara normal dan pada gambar IV.2 grafik plot terlihat titik-titiknya mengikuti garis diagonalnya. Jadi pada kedua grafik tersebut bisa disimpulkan bahwa data dinyatakan berdistribusi normal.

Tabel. 2 Uji Normalitas Kolmogorov Smirnov Setelah Pengurangan Nilai Outlier One - Sample Kolmogorov - Smirnov Test

\begin{tabular}{|ll|r|}
\hline & & $\begin{array}{r}\text { Unstandardized } \\
\text { Residual }\end{array}$ \\
\hline $\mathrm{N}$ & Mean & 143 \\
Normal & Std. & $0.00 \mathrm{E}+00$ \\
Parameters & Deviation & 1.17083131 \\
Most & Absolute & 0.048 \\
Extreme & Positive & 0.048 \\
Differences & Negative & -0.024 \\
Kolmogorov-Smirnov Z & 0.579 \\
Asymp. Sig. (2-tailed) & 0.891 \\
\hline
\end{tabular}

Tampilan hasil output pada tabel IV.2, bisa diamati dari hasil Asymp. Sig. (2-tailed) sebanyak 0.891, di mana hasilnya itumelebihi 0.05. Atau perolehan hasil signifikan 0.891>0.05. Maka data dinyatakan berdistribusi normal. Data yang baik harus memenuhi syarat asumsi normalitas atau data berdistribusi normal, sehingga periset melakukan pengurangan data pengamatan yang memiliki nilai outlier. Sehingga jumlah data pengamatan yang diuji menjadi 143 data.

\section{Uji Multikolinearitas}

Pengujian multikolinearitas bertujuan untuk mendeteksi apakah antara variabel independen menimbulkan multikolinier ataupun tidak dan di bagian regresi apakah terkandung korelasi dengan nilai tinggi atau sempurna antar variabel independen. (Ghozali, 2018)

Tabel 3 Uji Multikolinearitas

\section{Coefficients $^{\mathrm{a}}$}

\begin{tabular}{|l|l|l|}
\hline \multirow{2}{*}{ Model } & \multicolumn{2}{|l|}{ Collinearity Statistics } \\
\cline { 2 - 3 } & Tolerance & VIF \\
\hline (Constant) & & \\
CR & .537 & 1.862 \\
DAR & .473 & 2.115 \\
\hline
\end{tabular}




\begin{tabular}{|l|l|l|} 
RoA & .724 & 1.381 \\
Ukuran & .962 & 1.039 \\
\hline
\end{tabular}

Pada pengujian Multikolinieritas menunjukkan hasil Tabel Data, dimana hasil tolerancenyapada seluruh variabel diatas $\geq 0.01$ dan hasilVIFpada seluruh variabel $\leq 10$. Sehingga bisa dibuktikan berdasarkan pengujian ini, data tersebut terbebas atau tidak ada gejala Multikolinieritas

\section{Uji Autokorelasi}

Pengujian autokorelasi bermaksud untukmelihat model regresi linear apakah mempunyai correlation terhadap kekeliruan pengganggu di masa $t$ dan kekeliruan pengganggu pada masa $t$ 1sebelumnya. (Ghozali, 2018)

Tabel 4 Uji Autokorelasi

\begin{tabular}{|r|c|r|l|l|l|}
\hline \multicolumn{7}{|c|}{ Model Summary } \\
\hline Model & $\mathrm{R}$ & R Square & Adjusted R Square & Std. Error of the Estimate & Durbin - Watson \\
\hline 1 & $.0744^{\mathrm{a}}$ & 0.553 & .540 & 1.18768 & 2.144 \\
\hline
\end{tabular}

Diketahui bahwa Uji Autokorelasi merupakan uji yang menilai adanya autokorelasi pada residual. Pada tabel IV.4 memperlihatkan bahwa hasil Durbin-Watson sebanyak 2.144. Rumus agar mencegahtimbulnya Autokorelasi yaitu DU < DW < 4 - DU.

Apabila hasil nilai DW sebanyak 2.144, dan hasil DU didapatkan melalui tabel Durbin Watson. Berdasarkan ketentuan $\mathrm{K}$ merupakan variabel independen yaitu 4 dan $\mathrm{N}$ merupakan seluruh data yaitu 143, maka DU nya sebesar 1.7846. Setelah di isi angka-angka tersebut pada Rumus Uji Autokorelasi, maka menunjukkan hasil 1.7846<2.144<2.2154 (4 - 1.7846). Awalnya hasil DU kurang darihasil DW, yang kemudian hasil DW kurang dari 4 - DU. Oleh karena itu, hasil tersebut bisa dinyatakan bebas dari masalah atau gejala autokorelasi.

\section{Uji Heteroskedastisitas}

Ghozali (2018) mengatakan bahwa pengujian heteros-kedastisitas dipakai agar mendeteksi keberadaaan model regresi yang menimbulkan ketidaksetaraan variant dari residual suatu observasi dengan observasi lainnya.

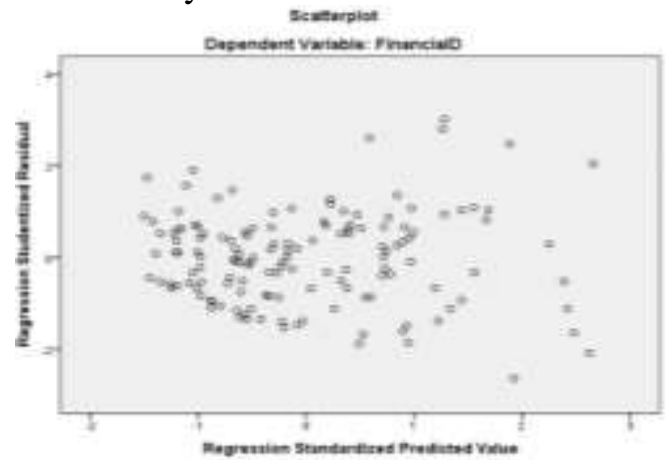

\section{Gambar IV.3 Grafik Scatterpot Uji Heterokedastisitas}

Berdasarkan Gambar IV.3 , grafik tersebut memperlihatkan bahwa titik - titik tersebut berpencar secara random atau tidak beraturan, hingga dapat disimpulkan bahwa data tersebut terbebas dari gejala Heteros-kedastisitas.

Tabel 5 Uji Spearman 


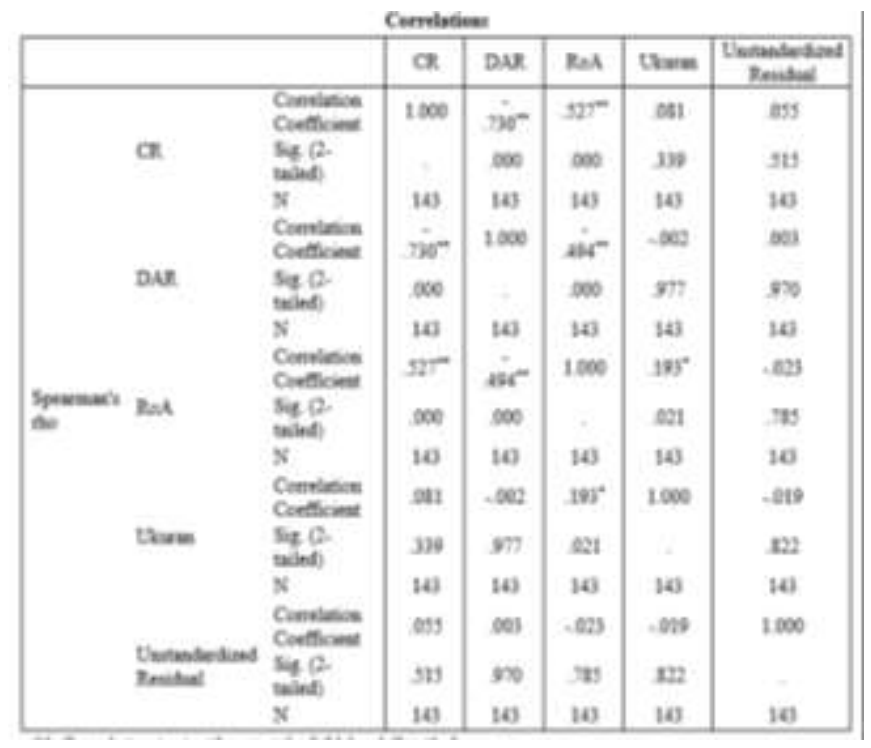

Hasil output Tabel Uji Heteros-kedastisitas yang menggunakan Uji spearman, dimana hasil dari seluruh nilai Sig. pada tabel IV.5 ini menunjukkan nilai Sig. $>0.05$, jadi disimpulkan data tidak terdapat gejala Heteros-kedastisitas.

\section{Uji Asumsi Klasik}

\section{Analisis Regresi Linear Berganda}

Bentuk persamaan dari analisis regresi linear berganda yaitu :

$$
Y=a+b_{1} X_{1}+b_{2} X_{2}+b_{3} X_{3}+b_{4} X_{4}+e
$$

Keterangan:

$$
\begin{array}{ll}
\mathrm{Y} & =\text { Financial Distress } \\
\mathrm{a} & =\text { Konstanta } \\
\mathrm{X} 1 & =\text { Likuiditas }(\mathrm{CR}) \\
\mathrm{X} 2 & =\text { Leverage (DAR) } \\
\mathrm{X} 3 & =\text { Profitabilitas (RoA) } \\
\mathrm{X} 4 & =\text { Ukuran Perusahaan } \\
\mathrm{b} 1 \ldots \mathrm{b} 4 & =\text { Koefisien Regresi } \\
\mathrm{e} & =\text { Variabel pengganggu }
\end{array}
$$

Tabel.6 Persamaan Analisis Regresi Linear Berganda
\begin{tabular}{|l|c|c|c|}
\hline \multirow{3}{*}{ Coefficients } \\
\hline \multirow{3}{*}{ Model } & \multicolumn{2}{|c|}{$\begin{array}{c}\text { Unstandardized } \\
\text { Coefficients }\end{array}$} & $\begin{array}{c}\text { Standardized } \\
\text { Coefficients }\end{array}$ \\
\cline { 2 - 4 } & $\mathrm{B}$ & $\begin{array}{c}\text { Std. } \\
\text { Error }\end{array}$ & Beta \\
\hline (Constant) & 2.803 & 1.276 & \\
CR & .151 & .121 & .096 \\
DAR & -.473 & .806 & -.049 \\
RoA & 28.000 & 2.750 & .681 \\
Ukuran & -.0 .78 & -.074 & -.061 \\
\hline
\end{tabular}

Pada Tabel Persamaan Regresi Linear Berganda, bisa disusun dengan persamaan:

Financial Distress $=\mathbf{2 . 8 0 3}+0.151 \mathrm{CR}-0.473$ DAR +28.000 RoA -0.078 Ukuran

Berdasarkan hasil persamaan diatas, peneliti memperoleh penjelasan sebagai berikut: 
1. Nilai Konstanta sebanyak 2.803 yang dimaksud adalah CR, DAR, RoA, dan Ukuran sama dengan stabil atau bernilai Nol, maka Financial distress (Y) mengalami peningkatan sebanyak 2.803.

2. CR sebanyak 0.151 yang artinya setiap peningkatan atau perubahan pada rasio ini, maka Financial Distress (Y) positif atau dapat menghadapi kenaikan sebanyak 0.151.

3. DAR sebesar -0.473 yang artinya setiap peningkatan atau perubahan pada rasio ini, maka Financial Distress (Y) menjadi negatif atau akan menghadapi penurunan sebanyak -0.473 .

4. RoA sebesar 28.000 yang artinya setiap peningkatan atau perubahan pada rasio ini, maka Financial Distress (Y) bernilai positif atau akan mengalami peningkatan sebesar 28.000.

5. Ukuran sebanyak -0.078 bahwa setiap kenaikan atau perubahan pada rasio ini, sehingga Financial Distress (Y) bernilai negatif atau dapat menghadapi penurunan sebesar -0.078 .

\section{Koefisien Determinasi}

Pengujian Koefisien Determinasi dimaksud sebagai memperkirakan ukuran atas kapabilitas ragam saat menjelaskan variasi variabel terikat. (Ghozali, 2018)

Tabel 7 Uji Koefisien Determinasi

\begin{tabular}{|r|c|r|l|l|l|}
\hline \multicolumn{9}{|c|}{ Model Summary } \\
\hline Model & \multicolumn{1}{|c|}{ R } & R Square & Adjusted R Square & Std. Error of the Estimate & Durbin - Watson \\
\hline 1 & $.0744^{\mathrm{a}}$ & 0.553 & .540 & 1.18768 & 2.144 \\
\hline
\end{tabular}

Dengan mengamati tingkat pengaruh variabel $\mathrm{X}$ pada variabel $\mathrm{Y}$ bisa diamati dari Adjusted R Square. Pada tabel IV.7 ini memperlihatkan bahwa Nilai tersebut sebanyak 54\% yang artinya Financial Distress dapat diuraikan oleh variabel Likuiditas(CR), Leverage(DAR), Profitabilitas(RoA), Ukuran Perusahaan. Untuk sisa nya sebesar $46 \%$ berasal dari faktor lain di luar variabel peneliti seperti Inflasi, Rasio Aktivitas, Arus Kas, atau variabel lainnya.

\section{Pengujian Parsial (Uji T)}

Pengujian Statistik $\mathrm{T}$ bermaksud mengecek keberadaan tiap variabel Independent (Variabel X) yang mempunyai pengaruh terhadap variabel Dependent (Variabel Y). (Ghozali, 2018)

\section{Tabel 8 2Pengujian Secara Parsial (Uji T)}

\begin{tabular}{|l|l|l|}
\hline \multicolumn{2}{|c|}{ Coefficients } \\
\hline Model & $\mathrm{t}$ & Sig. \\
& & \\
\hline (Constant) & 2.196 & 0.30 \\
CR & 1.241 & .217 \\
DAR & -.587 & .558 \\
RoA & 10.183 & .000 \\
Ukuran & -1.053 & .294 \\
\hline
\end{tabular}

Besarnya $\mathrm{T}_{\text {tabel }}$ pada alpha 0,05 (two - tailed), dengan df sebesar 138 adalah 1.97730, maka penjelasan untuk tabel diatas adalah :

1. Likuiditas dengan menggunakan Current Ratio memperoleh hasil $\mathrm{T}_{\text {hitung }}(1.241)<\mathrm{T}_{\text {tabel }}(1.97730)$ dan hasil signifikansi $(0.217)>0.05$, maka $\mathrm{H}_{1}$ ditolak yang berarti Secara parsial, Likuiditas tidak signifikan dan berpengaruh positif terhadap Financial Distress.

2. Leverage yang menggunakan Debt to Asset Ratio memperoleh hasil $-\mathrm{T}_{\text {hitung }}(-0.587)>-\mathrm{T}_{\text {tabel }}(-$ 1.97730) dan hasil signifikansi(0.558) >0.05, maka $\mathrm{H}_{2}$ ditolak yang berarti Secara parsial, Leverage tidak signifikan dan berpengaruh negatif terhadap Financial Distress. 
3. Profitabilitas dengan menggunakan Return on Assets memperoleh hasil $\mathrm{T}_{\text {hitung }}(10.183)>\mathrm{T}_{\text {tabel }}$ (1.97730) dan hasil signifikansi $(0.000)<0.05$, maka $\mathrm{H}_{3}$ diterima yang berarti Secara parsial, Profitabilitas ini signifikan dan berpengaruh positif terhadap Financial Distress.

Ukuran Perusahaan memperoleh hasil $-\mathrm{T}_{\text {hitung }}(-1.053)>-\mathrm{T}_{\text {tabel }}(-1.97730)$ dan hasil signifikansi $(0.294)>0.05$, maka $\mathrm{H}_{4}$ ditolak yang berarti Secara Parsial, Ukuran Perusahaan tidak signifikan dan berpengaruh negatif terhadap Financial Distress.

\section{Pengujian Simultan (Uji F)}

Pengujian Simultan F dipakai agar mendapatkan informasi mengenai tidak atau adanya pengaruh dengan bersamaan antar variabel $\mathrm{X}$ (Variabel Independent) terhadap variabel $\mathrm{Y}$ (Variabel Dependent). (Ghozali, 2018)

\begin{tabular}{|l|c|c|}
\hline \multirow{2}{*}{ Model } & \multicolumn{2}{|c|}{ Collinearity Statistics } \\
\cline { 2 - 3 } & Tolerance & VIF \\
\hline (Constant) & & \\
CR & .537 & 1.862 \\
DAR & .473 & 2.115 \\
RoA & .724 & 1.381 \\
Ukuran & .962 & 1.039 \\
\hline
\end{tabular}

\section{Tabel IV. 9 Pengujian Secara Simultan (Uji F)}

Berdasarkan tabel IV.9, menyatakan hasil signifkasi (0.000) tidak melebihi 0.05. Hasil $\mathrm{F}_{\text {tabel }}$ pada Df (1) ialah 4 dan Df (2) ialah 138 yaitu 2.44. Dengan melihat hasil uji $\mathrm{F}$ hitung diperoleh $42.757>\mathrm{F}$ tabel 2.44 yang dinyatakan bahwa seluruh variabel $\mathrm{X}$ yaitu, likuiditas dengan rasio CR, Leverage dengan rasio DAR, Profitabilitas dengan rasio RoA, Ukuran perusahaan secara signifikan mempengaruhi variabel Y (Financial Distress / kesulitan kondisi keuangan) pada perusahaan barang konsumsi yang terdaftar di Bursa Efek Indonesia periode 2016-2020.

\section{Pembahasan Hasil Penelitian}

\section{Pengaruh Likuiditas (CR) Terhadap Financial Distress}

Hasil riset studi peneliti, membuktikan bahwa besar kecilnya nilai Likuiditas dari suatu entitas belum tentu berdampak besar terhadap keadaan keuangan ataupun mengakibatkan kesulitan keuangan di Perusahaan Konsumsi yang Terdaftar di BEI Periode 2016-2020.

Likuiditas merupakan suatu cara bagaimana suatu entitas mendanai baik kegiatan operasional maupun hutang jangka pendeknya. Walaupun teori mengatakan Likuiditas berperan dalam mempengaruhi kondisi keuangan suatu Entitas melalui kemampuan membayar utang maupun kegiatan operasionalnya, akan tetapi kondisi ini tidak selalu berlaku sama. Sewaktuwaktu asset berbentuk piutang yang memfaktori hal ini. Sehingga dibutuhkan waktu yang lama untuk mengkonversikan piutang menjadi kas (cash). Maka kondisi ini mampu menjelaskan ketersediaan dana dalam bentuk piutang yang tidak mampu mempengaruhi kesulitan keuangan melalui waktu pencairannya.

Hasil ini sesuai dengan riset studi didasarkan oleh Aryadi (2018) dan (Widati \& Pratama, 2015) yang dimana hasil risetnya menunjukkan rasio likuiditas tidak mempengaruhi financial distress. Namun untuk riset studi dari Eminingtyas (2017) tidak sesuai dengan riset peneliti dimana likuiditas mempengaruhi Financial Distress. 


\section{Pengaruh Leverage (DAR) Terhadap Financial Distress}

Pada riset studi peneliti, memperlihatkan bahwa Leverage secara signifikan tidak mempengaruhi Financial Distress (kondisi kesulitan keuangan) di Perusahaan Konsumsi yang Terdaftar di BEI Periode 2016-2020.

Leverage memperlihatkan besarnya beban utang yang harus ditanggung perusahaan dalam rangka memenuhi aset perusahaan. Jika suatu perusahaan memiliki utang (kewajiban) cukup besar, tetapi memperoleh laba yang lebih besar ditambah dengan asset saat ini maka dana tersebut mampu menutupi kewajiban perusahaan sehingga kejadian tersebut tidak berpengaruh langsung terhadap financial distress (kesulitan keuangan). Pada PT. SKLT periode 2016-2017 memperlihatkan total kewajiban yang meningkat mampu meningkatkan laba. Sehingga kemampuan dalam memonitor leverage menjadi solusi yang mengarahkannya tidak berpengaruh terhadap kesulitan keuangan.

Hasil ini sesuai dengan riset studi didasarkan oleh (Carolina, I. Marpaung dkk, 2017) dan (Stephanie, Lindawati dkk, 2020) yang dimana hasil risetnya menunjukkan leverage tidak mempengaruhi financial distress. Namun untuk riset studi dari Azalia \& Rahayu (2019) tidak sesuai dengan riset peneliti dimana leverage mempengaruhi Financial Distress (kondisi kesulitan keuangan).

\section{Pengaruh Profitabilitas (RoA) Terhadap Financial Distress}

Dari riset studi peneliti, menunjukkan Profitabilitas secara signifikan mempengaruhi Financial Distress (kondisi kesulitan keuangan) di Perusahaan Konsumsi yang Terdaftar di BEI Periode 2016-2020.

Entitas dengan nilai Profitabilitas tinggi maupun rendah tentu sangat berpengaruh pada kondisi keuangan entitas. Dikarenakan Profitabilitas mampu menganalisa kondisi keuangan melalui laba yang diperoleh dalam membiayai berbagai jenis utang maupun biaya kegiatan operasional entitas lainnya sehingga financial distress yang tidak diharapkan dapat diatasi.

Hasil ini sepadan dengan riset studi didasarkan oleh Aryadi (2018), Yudhistira (2019) dan Oktavianti, Hizai, dkk (2020) yang dimana hasil risetnya menunjukkan profitabilitas mempengaruhi financial distress. Namun untuk riset studi dari Rohmadini, Saifi, dkk (2018) tidak sesuai dengan riset peneliti dimana profitabilitas tidak mempengaruhi financial distress.

\section{Pengaruh Ukuran Perusahaan Terhadap Financial Distress}

Pada riset studi peneliti, membuktikan Ukuran Perusahaan secara signifikan tidak mempengaruhi Financial Distress (kondisi kesulitan keuangan) di Perusahaan Konsumsi yang Terdaftar di BEI Periode 2016-2020.

Ukuran Perusahaan dengan asset yang banyak mampu mengetahui apakah perusahaan itu terjadi kesulitan keuangan ataupun tidak, akan tetapi apabila perusahaan tidak pandai mengelola assetnya dengan baik maka asset perusahaan itu akan menjadi menipis sehingga perusahaan terjadinya kerugian secara financial.

Hasil ini tidak sesuai dengan riset studi didasarkan oleh Oktavianti, Hizai, dkk (2020), Aryadi (2018) dan (Stephanie, Lindawati dkk, 2020) yang dimana hasil risetnya menunjukkan ukuran perusahaan tidak mempengaruhi financial distress. Namun untuk riset studi dari Silalahi, dkk (2018) dan Azalia \& Rahayu (2019) sesuai dengan riset peneliti dimana ukuran perusahaan mempengaruhi Financial Distress.

\section{KESIMPULAN}

Pada hasil riset peneliti dapat ditarik berupa kesimpulan, berikut adalah kesimpulannya :

1. Pada pengujian hipotesis $\mathrm{f}$, menunjukkan bahwa Likuiditas (CR), Leverage(DAR), Profitabilitas (RoA), dan Ukuran Perusahaan bersama - sama secara signfikan mempengaruhi Financial Distress(kondisi kesulitan keuangan) pada perusahaan barang konsumsi yang terdaftar di BEI pada tahun $2016-2020$. 
2. Pada pengujian secara parsial, Likuiditas yang memanfaatkan (Current Ratio) menunjukkan tidak signifikan dan berpengaruh positif terhadap Financial Distress (kondisi kesulitan keuangan).

3. Pada pengujian secara parsial, Leverage yang memanfaatkan (Debt to Asset Ratio) menunjukkan tidak signifikan dan berpengaruh negatif terhadap Financial Distress (kondisi kesulitan keuangan).

4. Pada pengujian secara parsial, Profitabilitas yang memanfaatkan (Return on Assets) menunjukkan signifikan dan berpangaruh positif terhadap Financial Distress (kondisi kesulitan keuangan).

5. Pada pengujian secara parsial, Ukuran Perusahaan yang menggunakan perhitungan (Ln Total Asset) menunjukkan tidak signifikan dan berpangaruh negatif secara parsial terhadap Financial Distress.

\section{V.2 Kerbatasan dalam riset}

1. Sampel entitas yang periset kumpulkan memiliki keterbatasan dengan jumlah sampel 34 perusahaan dikarenakan sektor yang periset teliti tergolong sedikit.

2. Variabel bebas yang periset gunakan untuk memprediksi Financial Distress hanya terbatas seperti Likuiditas (CR), Leverage (DAR), Profitabilitas (RoA) dan Ukuran Perusahaan.

\section{V.3 Saran}

Bagi Peneliti berikutnya, bisamemperbanyak variabel bebas seperti Inflasi, Rasio Aktivitas, Arus Kas, atau variabel lainnya. dan Peneliti mampu memanfaatkan sampel perusahaan di sektor yang lebih besar. Bagi Perusahaan, Agar dapat menghindari financial distress dengan memperbanyak pendapatan lainnya seperti dari pendapatan dividen yang diperoleh dari pembelian saham perusahaan lain, pendapatan sewa, dan pendapatan bunga.

Bagi investor, apabila ingin mengetahui kondisi suatu perusahaan apakah terjadi risiko penurunan kondisi keuangan (financial distress), maka investor bisa melihat rasio keuangan seperti rasio profitabilitas. sehingga investor dapat menanamkan modalnya ke perusahaan tersebut dan terhindar dari kerugian.

\section{References}

Aryadi, M. A. (2018). Pengaruh Profitabilitas, Likuiditas, Leverage, dan Ukuran Perusahaan terhadap Financial Distress. Sekolah Tinggi Ilmu Ekonomi Perbanas.

Azalia, V., \& Rahayu, Y. (2019). Pengaruh Leverage, Likuiditas, Profitabilitas, dan Ukuran Perusahaan terhadap Financial Distress. Jurnal Ilmu dan Riset Akuntansi, 8(6), 1-16.

Brigham, \& Houston. (2017). Dasar-Dasar Manajemen Keuangan. Jakarta: Salemba Empat.

Carolina, V., Marpaung, E. I., \& Pratama, D. (2017). Analisis Rasio Keuangan untuk Memprediksi Kondisi Financial Distress (Studi Empiris pada Perusahaan Manufaktur yang Terdaftar di Bursa Efek Indonesia Periode 2014-2015). Jurnal Akuntansi Maranatha, Program Studi Akuntansi, Fakultas Ekonomi, Universitas Kristen Maranatha., 9(2), 137-145. doi:https://doi.org/10.28932/jam.v9i2.481

Eminingtyas, R. (2017). Pengaruh Ukuran Perusahaan, Likuiditas, Leverage, Sales Growth dan Operating Capacity terhadap Financial Distress pada Perusahaan Manufaktur (Terdaftar di BEI). Sekolah Tinggi Ilmu Ekonomi Perbanas.

Firdiana, M. L. (2016). Pengaruh Current Ratio, Return on Asset, Ukuran Perusahaaan dan Sales Growth terhadap Financial Distress. Sekolah Tinggi Ilmu Ekonomi Perbanas.

Gozali, \& I. (2018). Aplikasi Analisis Multivariate dengan Program IBM SPSS 25 (Edisi 9 ed.). Semarang: Undip.

Halim, A., M., M., \& Hanafi. (2009). Analisis Laporan Keuangan (Edisi 4 ed.). Yogyakarta: UPP STIM YKPN.

Jatmiko, B. P. (Ed.). (2018, 10 18). Sariwangi, Si Pelopor Teh Celup di Indonesia yang Berakhir Tragis. Retrieved from KOMPAS: https://ekonomi.kompas.com/read/2018/10/18/060810426/sariwangi-si-pelopor-teh-celupdi-indonesia-yang-berakhir-tragis?page $=$ all

Kasmir. (2016). Analisis Laporan Keuangan. Jakarta: Raja Grafindo Persada. 
Natsir, K., \& Liang, I. (2019). Pengaruh Profitabilitas, Likuiditas dan Ukuran Perusahaan terhadap Struktur Modal. Jurnal Manajerial dan Kewirausahaan (Vol. Vol. 1 No. 3).

Noviandani, N., \& Safitri, M. (2018). Analisis Altman Z-Score untuk Memprediksi Kebangkrutan pada Perusahaan Manufaktur Sektor Barang Konsumsi di Indonesia. The National Conferences Management and Business (NCMAB), 141-157.

Oktavianti, B., Hizai, A., \& Mirdah, A. (2020). Pengaruh Likuiditas, Profitabilitas, Leverage dan Ukuran Perusahaan terhadap Financial Distress pada Perusahaan Pertambangan yang Terdaftar di Bursa Efek Indonesia Periode Tahun 2015-2018. Jambi Accounting Review (JAR), 1(1), 20-34.

Riyanto, B. (2013). Dasar-Dasar Pembelanjaan Perusahaan. Yogyakarta: BPFE.

Rohmadini, A., Saifi, M., \& Darmawan, A. (2018). Pengaruh Profitabilitas, Likuiditas dan Leverage terhadap Financial Distress (Studi Pada Perusahaan Food \& Beverage yang Terdaftar di Bursa Efek Indonesia Periode 2013 - 2016). Jurnal Administrasi Bisnis (JAB), 61(2), 11-19.

Silalahi, H. R., Kristanti, F. T., \& Muslih, M. (2018). Pengaruh Rasio Keuangan dan Ukuran Perusahaan Terhadap Kondisi Kesulitan Keuangan (Financial Distress) Pada Perusahaan Sub-Sektor Transportasi yang Terdaftar di Bursa Efek Indonesia (BEI). E-Proceeding of Management, 5(1), 796-802.

Stephanie, Lindawati, Suyanni, Christine, Oknesta, E., \& Afiezan, A. (2020). Pengaruh Likuiditas, Leverage dan Ukuran Perusahaan terhadap Financial Distress pada Perusahaan Properti dan Perumahan. Journal of Economic, Business and Accounting, 3(2), 300-310. doi:https://doi.org/10.31539/costing.v3i2.1122

Sugiyono. (2017). Metode Penelitian Kuantitatif, Kualitatif, dan R\&D. Bandung: Alfabeta.

Sugiyono. (2018). Metode Penelitian Kuantitatif, Kualitatif, dan R\&D. Bandung: Alfabeta.

Syafina, D. C. (Ed.). (2018, 10 18). Kenapa Perusahaan Teh Sariwangi Bisa Pailit? Retrieved from Tirto.id: https://tirto.id/kenapa-perusahaan-teh-sariwangi-bisa-pailit-cUoh

Widati, L. W., \& Pratama, B. A. (2015). Pengaruh Current Ratio, Debt to Equity Ratio, dan Return on Equity untuk Memprediksi Kondisi Financial Disress. Prosiding Seminar Nasional Multi Disiplin Ilmu \& Call For Papers Unisbank (Sendi_U).

Yudhistira, H. (2019). Pengaruh Leverage dan Profitibalitas terhadap Financial Distress (Pada Perusaahaan Manufaktur yang Terdaftar di BEI). Jurnal Ilmiah Mahasiswa FEB, Universitas Brawijaya, 7(2). 